\title{
ORGANIC MATTER FLUX IN THE EPIKARST OF THE DORVAN KARST, FRANCE
}

\author{
TOK ORGANSKE SNOVI V EPIKRASU: PRIMER KRAŠKEGA \\ SISTEMA DORVAN, FRANCIJA
}

Kevin S. SIMON ${ }^{1}$

\begin{abstract}
UDC 551.44:556.33:543.38(445.61)

Kevin S. Simon: Organic matter flux in the epikarst of the Dorvan karst, France

Availability of organic matter plays an important role in karst ecosystems. Somewhat surprisingly, study of the composition and distribution of organic matter in karst aquifers is rare. The most comprehensive study or organic matter flux to date is a two year continuous monitoring of detritus and animal flux in epikarst drip waters and an epikarst-fed cave stream in the Dorvan karst, France. Analysis of those data reveals high temporal variation in detritus and animal flux in both habitats, but little evidence of seasonality in flux. Water flux explained $30-69 \%$ of the variation in animal flux in both habitats and detritus flux in the epikarst seepage water. Detritus flux in the cave stream was better explained by peak monthly discharge. Lack of coherence between organic matter flux in epikarst seepage and the epikarst stream suggests organic matter transport is governed by differing factors in the two habitats. Overall, much of the particulate organic matter flux in the epikarst occurs as living animals suggesting a dominant role of ecological processes in organic matter transport.
\end{abstract}

Keywords: Carbon, energy, epikarst, flux, seasonality, stream.
Izvleček

UDK 551.44:556.33:543.38(445.61)

Kevin S. Simon: Tok organske snovi v epikrasu: Primer kraškega sistema Dorvan, Francija

Kljub temu, da gre za pomembne dejavnike kraških ekosistemov, obstajajo le redke študije o sestavi in porazdelitvi organske snovi v kraških vodonosnikih. $\mathrm{V}$ članku predstavimo rezultate dveletnega zveznega opazovanja toka detrita in organizmov (živali) $\mathrm{v}$ prenikli vodi in $\mathrm{v}$ jamskem potoku, ki ga napaja epikras, v kraškem sistemu Dorvan, Francija. V obeh okoljih smo zaznali veliko časovno spremenljivost opazovanih parametrov, ki pa ni bila sezonske narave. 30-69\% spremenljivosti pretoka živali v obeh habitatih in detrita v epikraški prenikli vodi, lahko povežemo s spremenljivostjo pretoka. Pretok detrita v jamskem potoku pa je povezan $\mathrm{z}$ največjimi mesečnimi pretoki. Različne značilnosti pretoka organske snovi v obeh opazovanih habitatih, kažejo na različne dejavnike vpliva. Živi organizmi tvorijo večino toka organskih delcev, kar kaže na velik pomen ekoloških procesov v prenosu organske snovi.

Ključne besede: ogljik, energija, epikraški tok, sezonskost, potok.

\section{INTRODUCTION}

Caves are typically thought to be energy limited ecosystems with food webs that rely on either dead organic matter, detritus, imported from surface soils and vegetation (Hüppop 2000; Poulson \& Lavoie 2001; Simon et al. 2007) or on internal chemoautotrophic production (Sar- bu et al. 1996). Indeed, a suite of life history characters of cave animals have been considered to be adaptations to low energy availability in caves (see Hüppop 2000 for a review). Such a strong role of energy availability in the ecology and evolution of cave animals suggests a clear

\footnotetext{
${ }^{1}$ School of Environment, The University of Auckland, Private Bag 92019, Auckland 1142, New Zealand, Fax: 6493737434,

e-mail: k.simon@auckland.ac.nz
}

Received/Prejeto: 12.3.2013 
understanding of organic matter dynamics in cave systems is critical. Historically, this has not been the case with few studies directly examining the pattern and drivers of organic matter availability in caves and the subsequent consequences of variation in energy availability in cave systems. This is changing, however, with a growing body of research that addresses various facets of organic matter dynamics in caves.

Both dissolved and particulate organic matter appear to be important for aquatic cave fauna and the availability of these resources is partially a function of geology and surface features (Simon et al. 2007). For example, the presence of large openings and sinking streams should permit entry of large detrital particles (e.g. Souza-Silva et al. 2012) which appear to attract and be used by animals (Gibert et al. 1994). In contrast, soil layers and fine fractures in epikarst likely restrict movement of large particles into caves while permitting fine particle and dissolved organic matter entry. Dissolved organic matter (DOM) should be more universally available, but likely varies in quantity and composition based on flowpaths. The role of DOM for higher trophic levels have been examined (Simon et al. 2003; Cooney et al. 2009). Such studies have documented the importance of microbial production based in chemoautotrophy (Sarbu et al. 1996) and heterotrophy (Simon et al. 2009) for higher trophic levels. The importance of particulate organic matter (POM) for cave food webs is less well studied, but it also appears to serve as an important energy resource for at least some cave animals (Huntsman et al. 2011, Venarsky 2012). The pace and drivers of particulate organic matter decomposition has been examined in several cave systems (Simon et al. 2001; Kinsey et al. 2007; Huntsman et al. 2011; Venarsky et al. 2012). Such studies have suggested strong interactions among consumers and microbial films in dictating decomposition rate of particulate detritus and its likely use in food webs.

While the importance and use of detritus in cave streams has been shown, surprisingly few studies have quantified the amount of detritus in caves, its composition, and factors that dictate detritus distribution. Such data are critically important as they determine the availability and distribution of suitable energy sources in caves. Examination of dissolved organic matter (DOM) composition (Birdwell \& Engel 2010; Simon et al. 2010) has illuminated multiple sources of DOM and temporal and spatial variation in its form and abundance. Standing stocks of various types of POM have been measured in a few cave systems (e.g. Simon et al. 2001; Huntsman et al. 2011; Venarsky 2012), but examination of its composition is limited (but see Hutchins et al. this issue). Transport of organic matter into and within caves has been poorly studied despite the fact that it is central to understanding energy distribution in caves. By combining transport distances and decomposition rates, Simon et al. (2001) found that litter turnover distances were quite short suggesting transport of detritus deep into caves may be quite limited. This pattern has yet to confirmed beyond a single cave system. Direct measures of transport into and within caves are quite rare. Graening et al. (2003), in what is the most complete energy budget for a cave system to date, reported annual rates of import and export of organic matter to two cave streams. He showed that flux of DOM exceeded POM, a phenonmenon previously shown by Gibert (1986) in a French aquifer. Souza-Silva et al. (2012) measured bi-monthly flux of detritus into a Brazilian cave, showing high variation and seasonality of detritus import to a cave stream fed by a sinking stream.

The most comprehensive study to date detailing the dynamics of organic matter flux in an epikarst-fed cave system is that of the Dorvan karst by Gibert (1986). Over a two year period she measured flux of particulate detritus and animals in epikarst drips and a cave stream at high temporal resolution (days to months). Her data from over 30 years ago remain the single most comprehensive study of organic matter flux in a cave system. As such, they provide a unique opportunity to examine the relative magnitude of organic matter flux in dead and living forms and to address factors that dictate that flux. I reanalyzed Gibert's data with the goal of answering the following: 1) how large is the variation in organic matter flux in the epikarst, is that variation seasonal, and what factors dictate that variation? 2) how does organic matter transport as detritus and animals compare and are they likely regulated by the same factors?

\section{METHODS}

The Dorvan-Cleyzieu aquifer is a $10 \mathrm{~km}^{2}$, low-mountain karst (average altitude $620 \mathrm{~m}$ and average gradient $126 \mathrm{~m} / \mathrm{km}$ ) situated on the southwestern range of the Southern Jura mountains of France (see Gibert 1986 for a detailed description). It lies in middle Jurassic limestone (Bathonian and Bajocian) $50 \mathrm{~km}$ from the city of Lyon. At the top of the aquifer, the epikarst is drained by the Cormoran Cave stream (mean annual discharge $4.2 \mathrm{~L} / \mathrm{s}$ ). In- 
side Cormoran Cave, drips from the ceiling permit direct sampling of water exiting the epikarst. There are no large openings or sinking streams that feed Cormoran Cave so water entering the system must travel through soils and fractures in the epikarst. Water traveling through the aquifer ultimately exits at Pissoir Spring (mean annual discharge $76.5 \mathrm{~L} / \mathrm{s}$, range: 0 to 2,000 L/s) and from several seeps around the spring. Pissoir Spring acts as an overflow for the aquifer, flowing only when the water level in the aquifer reaches a sufficient height. After exiting the aquifer, water from the spring joins the Bief Ravinet stream and flows through an alluvial plain to the Albarine River.

The annual hydrologic cycle consists of a high-water period during winter characterized by relatively high discharge and frequent floods. During summer, water levels are generally low with the Cormoran Cave stream maintaining very low flow while the Pissoir Spring flows only intermittently. Vegetation covers $80-90 \%$ of the ground surface (meadows and crops $50 \%$, forests $40 \%$, moors and bushes 10\%). Agriculture on the surface has had some influence on groundwater quality, with chloride and nitrate concentrations ranging up to 8 and $14.7 \mathrm{mg} / \mathrm{L}$, respectively, on some occasions in the Cormoran Cave stream (Gibert 1986 \& 1990; Simon et al. 2001).

Detritus and animals in the Cormoran Cave stream and a series of epikarst drips were collected continuously from March 1978 to February 1980. A barrier was installed in the Cormoran Cave stream that directed the entire stream flow into two $150 \mu \mathrm{m}$ nets, one that sampled surface flow and a second that sampled transport below the surface. Data from the two nets were combined for analysis in this paper to analyze total flux in the stream. Water level at the barrier was continuously recorded and converted to discharge with a rating curve. A series of epikarst drips in a $6 \mathrm{~m}^{2}$ area of the cave ceiling adjacent and above the stream were directed with a waterproof tarpaulin into a $100 \mu \mathrm{m}$ net and container. Total water accumulating in the container was measured to calculate water flux between sampling periods. Contents of the nets were collected at irregular intervals ranging from 2 days to 2 weeks over the 2 year period. Invertebrates were identified and counted, but not weighed. Remaining material in the nets was dried at $70^{\circ} \mathrm{C}$, weighed to calculate dry mass, combusted at $550^{\circ} \mathrm{C}$, and then reweighed to determine mineral mass. Organic matter mass was calculated as the difference between dry mass and the mass of mineral material remaining after combustion.

I used the high-frequency sampling data archived in Gibert (1986) to calculate fluxes (mass per unit sampling period) and concentrations (mass per volume) of dead organic matter (detritus), mineral matter, and groundwater animals exiting the epikarst drips and in the cave stream on a monthly basis. The aquatic fauna in the drift were dominated by amphipods (Niphargus rhenorhodanensis) and harpactacoid and cyclopoid copepods, so I restricted my analysis to those taxa. Because animals were counted but not weighed I converted drift density to mass using conversion factors specific to the Dorvan karst for Niphargus and values for other freshwater taxa for copepods. Niphargus drift density was converted to biomass using a value of $5.58 \mathrm{mg} /$ individual, which was the average of 44 male and 50 female Niphargus collected from the Dorvan groundwater in 1980 (Gibert 1986). Harpactacoid density was converted to mass using a conversion factor of $0.0046 \mathrm{mg} /$ individual, a mean of ten freshwater epibenthic harpactacoid taxa (Goodman 1979). Cyclopoid density was converted to mass using a value of $0.0014 \mathrm{mg} /$ individual from surface stream cyclopoids (O’Doherty 1985). Total mass of copepods was calculated as the sum of haracticoid and cyclopoid copepods.

I compared temporal patterns in organic, inorganic and animal drift using Pearson correlation analysis. Relationships between monthly flux of detritus and animals and flux of water were examined using linear regression. The relationship between organic matter and mineral matter export was examined using standard major axis regression on the high frequency data. Monthly concentrations of detritus and animals in the epikarst and in the cave stream were compared using paired T-tests. Results were considered statistically significant at $\alpha=0.05$. All statistical analysis were performed using R (R Core Development Team 2010) and I used the lmodel2 package for SMA regression.

\section{RESULTS}

The monthly flux of detritus, Niphargus and copepods varied by 2 orders of magnitude in the cave stream over the two year period (Fig. 1). There was no obvious seasonality in flux although lowest values tended to occur in late summer and autumn. Niphargus flux exceeded detritus by about an order of magnitude in all but one month. The flux of organic matter as copepods was several orders of magnitude lower than detritus and Niphargus. The 


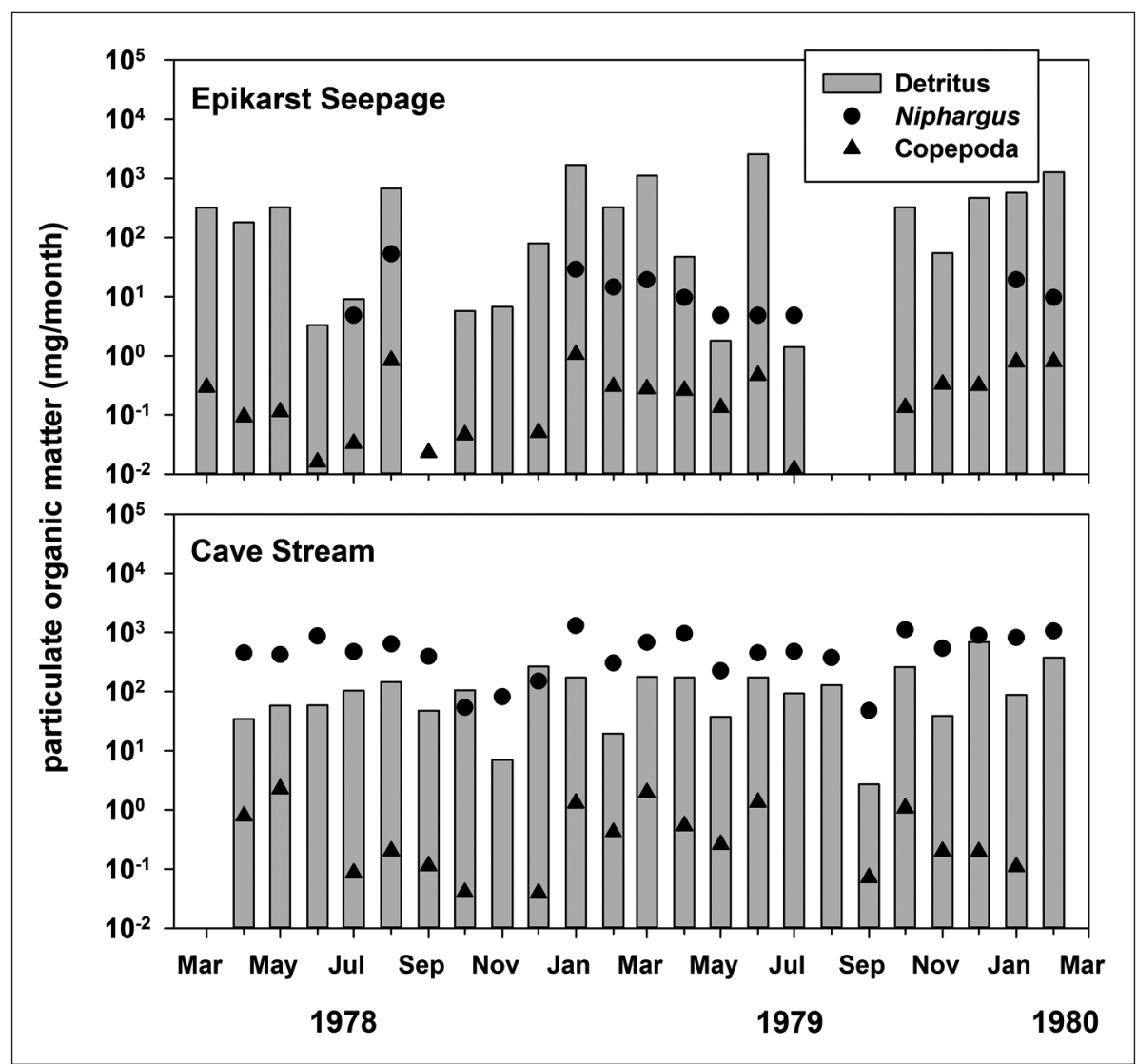

Fig. 1: Monthly flux of particulate organic matter as detritus, Niphargus and copepods in water seeping from the epikarst and in the Cormoran Cave stream. fluxes of detritus and Niphargus were positively correlated $(\mathrm{p}=0.017, \mathrm{r}=0.49)$, but neither was correlated with copepod flux ( $p>0.960)$.

In the epikarst, detritus and animal flux were more variable with detritus and, particularly, Niphargus flux absent in several months (Fig. 1). There was over 3 orders of magnitude variation in detritus and somewhat lower range in animal flux across months. Unlike the cave streams, flux of detritus nearly always exceeded flux of animals, largely due to low flux or absence of Niphargus. As in the cave stream, there was no obvious seasonality in flux although low values were common in late summer and autumn. Overall, there was no correlation between the epikarst and the stream for flux of detritus $(\mathrm{p}=0.263)$, Niphargus $(\mathrm{p}=0.090)$ or copepods $(\mathrm{p}=0.426)$.

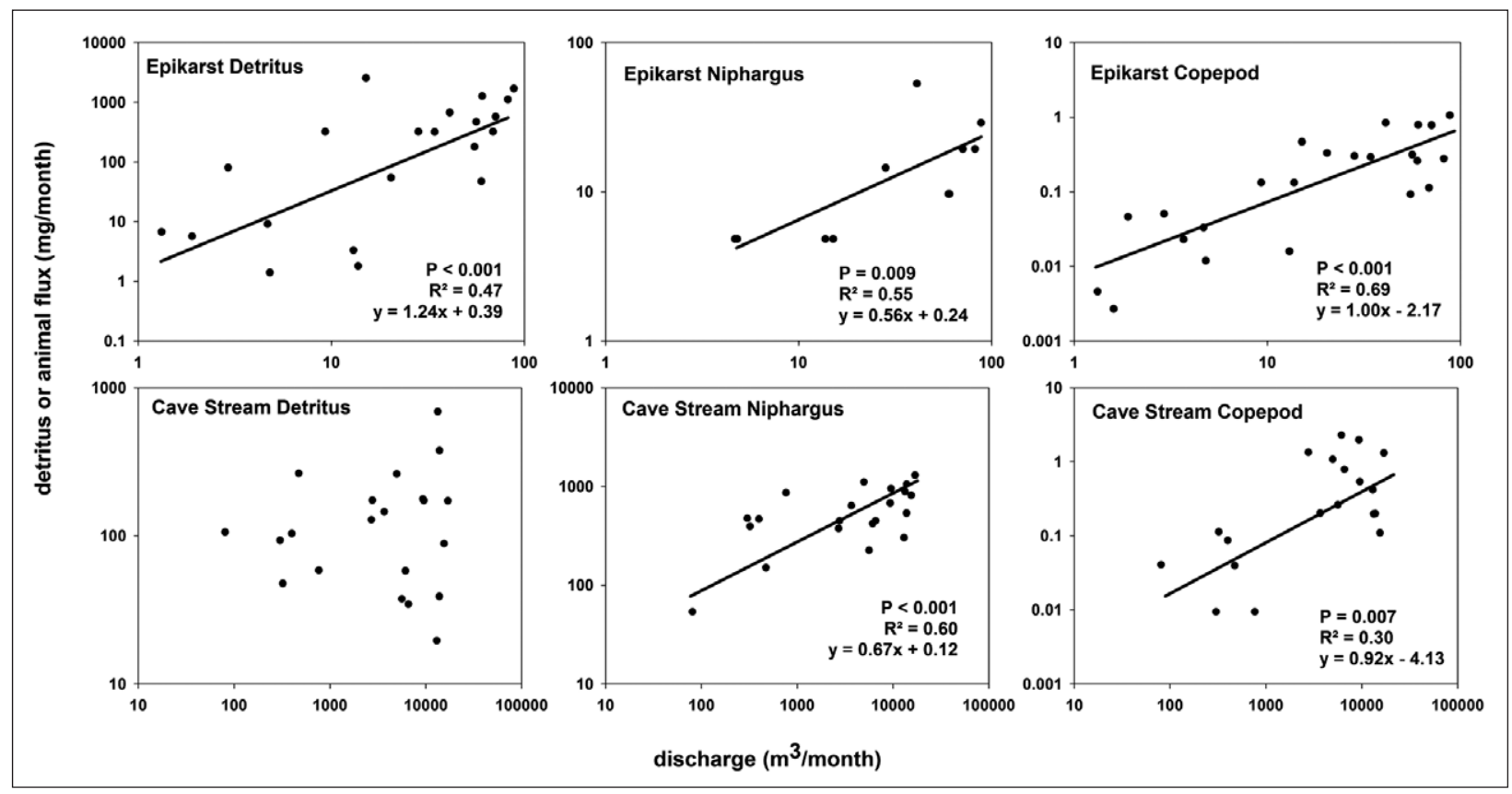

Fig. 2: Relationship between detritus or animal flux and discharge over the 2 year study period in the epikarst seepage water and the Cormoran Cave stream. Lines and statistical values are results of linear regressions of log 10 transformed data. 


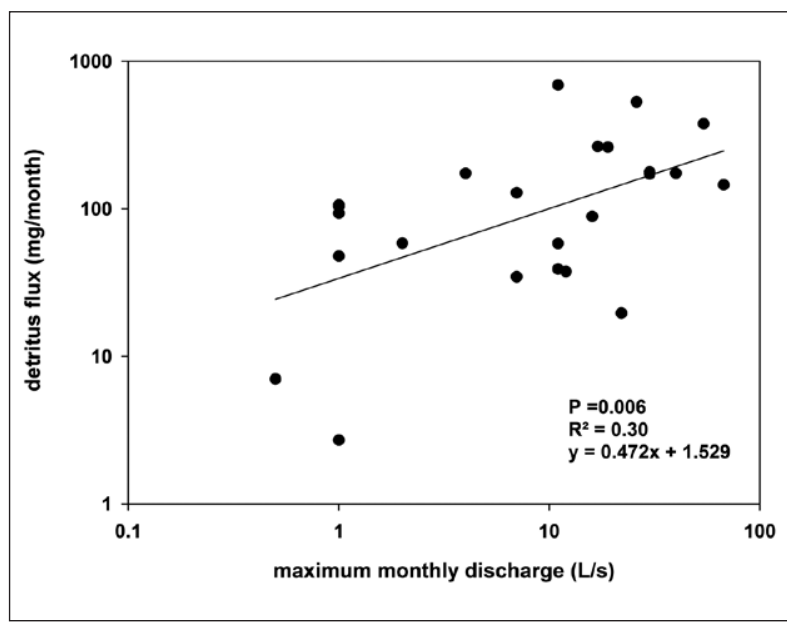

Fig. 3: Relationship between monthly flux of detritus and maximum monthly discharge in the Cormoran Cave stream over the 2 year study period.

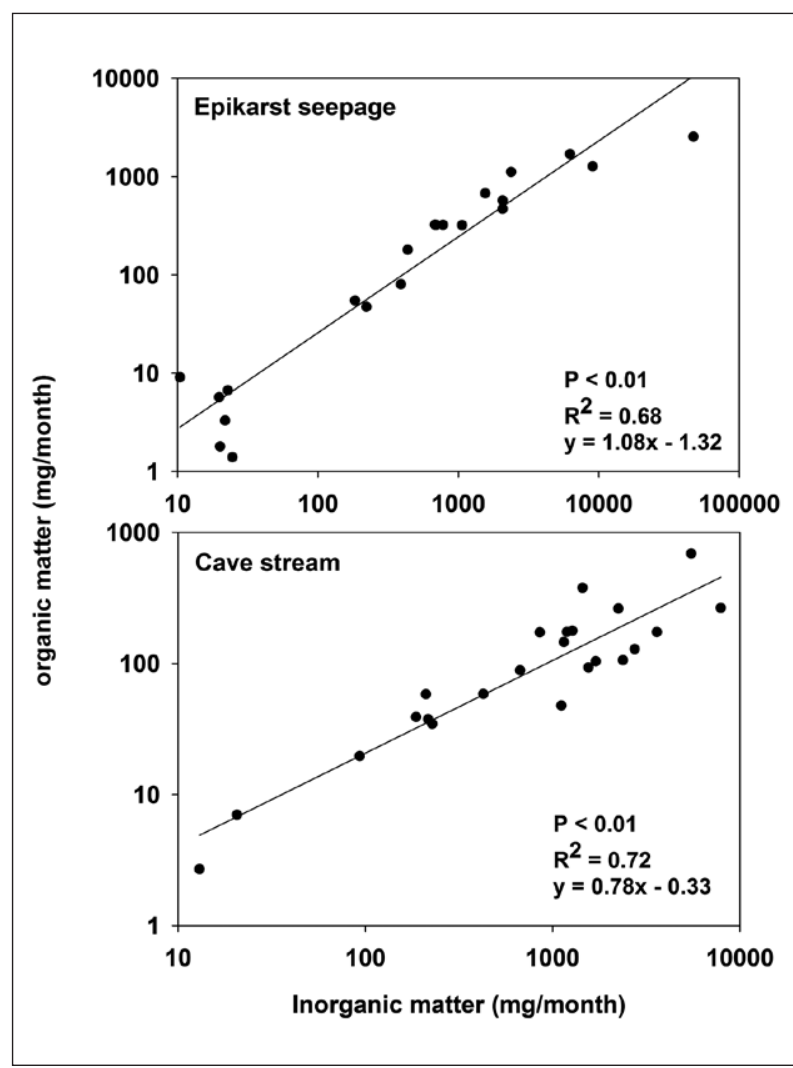

Fig. 4: Relationship between detritus flux and mineral material flux in epikarst seepage water and the Cormoran Cave stream. Statistical parameters are results of standardized major axis regressions.
Variation in discharge explained $30-69 \%$ of the monthly variation of animals in both the epikarst and the cave stream and $47 \%$ of the variation in detritus flux from the epikarst. Notably, monthly variation in detritus flux in the stream was unrelated to variation in discharge (Fig. 2)

While total water flux did not predict detritus flux, maximum monthly discharge explained about $30 \%$ of the variation in detritus flux in the cave stream (Fig. 3). The flux of detritus and mineral matter were highly correlated in both the cave stream and the epikarst (Fig. 4) with a SMA slope close to one (1.08) in the epikarst and slightly lower (0.78) in the cave stream. In contrast, the flux of Niphargus and copepods were unrelated $(p>0.23)$ to flux of mineral material.

Concentrations of detritus, Niphargus and copepods varied by $1-3$ orders of magnitude over time in the epikarst and cave stream water, but displayed no particular seasonal pattern (Fig. 5). In the epikarst, concentrations of detritus exceeded that of animals. In the cave stream concentrations of Niphargus exceeded that of detritus and copepods. Concentrations of detritus and copepods were $>500(\mathrm{p}=0.047)$ and $>100(\mathrm{p}<0.001)$ times higher, respectively in the epikarst water than in the cave stream. There was no difference $(\mathrm{p}=0.068)$ in Niphargus concentration between habitats.

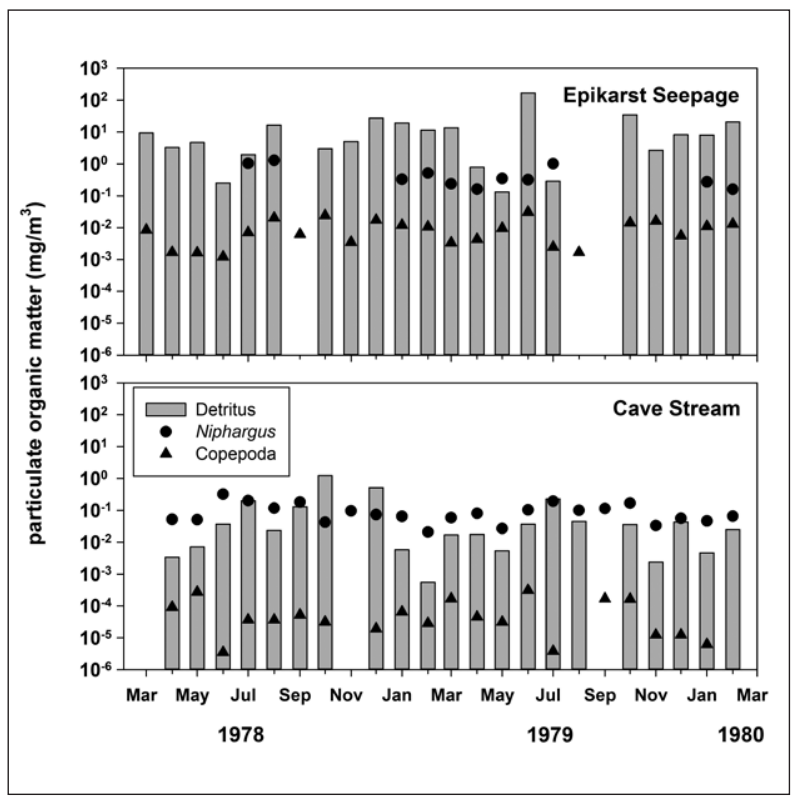

Fig. 5: Monthly concentrations of particulate organic matter as detritus, Niphargus and copepods in water seeping from the epikarst and in the Cormoran Cave stream. 


\section{DISCUSSION}

There was substantial variation in organic matter flux in the Drovan epikarst with up to several orders of magnitude variation among months for both detritus and animals. While the variation in flux was fairly large, there was a distinct lack of seasonality in the transport of organic matter in the epikarst drip water and the cave stream. In temperate forested surface streams as would have been typical of the Dorvan area, detritus input and transport is highly seasonal because of the temporal pattern of leaf fall (Benfield 1997). The lack of direct riparian input obviously changes the magnitude and timing of organic matter flux in cave streams compared to surface streams. Indeed, the epikarst-fed Cormoran Cave stream behaved more similarly to surface streams that lack riparian vegetation in desert and tundra landscapes (Schade \& Fisher 1997). The maximum concentration of organic matter in the cave stream $\left(0.129 \mathrm{mg} / \mathrm{m}^{3}\right)$ was more than three orders of magnitude lower than the lowest value reported across a range of surface streams $\left(210 \mathrm{mg} / \mathrm{m}^{3}\right.$, Golladay et al. 1991) demonstrating the scarcity of this energy source in the Cormoran Cave stream. Clearly, and not surprisingly, the epikarst provides an effective, if not complete, barrier to particulate matter influx to caves. This pattern is unlikely to be the case in all cave streams, particularly those with larger openings to the surface. For example, Souza-Silva (2012) found highly variable detritus input to a Brazilian cave with a seasonal pattern driven by rainfall and streamflow into the cave entrance. Flux of detritus to that cave stream (up to $263 \mathrm{~g} /$ day) far exceed the flux of detritus observed in Dorvan. Such streams with direct connectivity to the surface likely behave more similarly to related surface streams.

Temporal variation in detritus and animal flux was related to the amount of water moving through the systems, but water flux accounted for only 30-69\% variation in organic matter flux. In the cave stream, detritus flux was entirely unrelated to water flux. Clearly factors other than simple mass flux of water drive organic matter transport in epikarst seeps and streams. In the case of detritus in the cave stream, peak monthly discharge provided a better predictor of organic matter transport. This phenomenon has been observed in surface streams (Wallace et al. 1995) where detritus retention can be quite high and episodically driven by large flows that mobilize material from the streambed. This is probably even more common in cave streams with direct surface connection and highly variable flow. Future work on organic matter transport in caves should pay particular attention to periods of flow variation. Not only do high discharge events likely influence detritus transport, they appear to also influence micro- bial activity (Simon et al. 2001) providing the opportunity to couple organic matter transport with ecological consequences.

The relative pattern of detritus and animal flux in the epikarst and cave stream provides insight into how epikarst systems function. The lack of correlation in flux of detritus and animals between the epikarst and cave stream indicate different factors drive organic matter flux through the two habitats even though they are ultimately fed by the same system, i.e. surface soils and epikarst fractures. The bulk of organic matter exiting epikarst drips was detritus whereas it was predominantly amphipods in the cave stream. In addition, concentrations of detritus were higher in the epikarst drip water than in the cave stream. Gibert (1986) attributed lower detritus concentration in the cave stream to settling of detritus in the stream where it is presumably processed. Such detritus retention is typical of surface streams (Webster et al. 1999) and is consistent with short turnover lengths of leaf litter observed in cave streams (Simon et al. 2001). The closer relationship between detritus flux and water flux in the epikarst suggests a more passive process of bulk mobilization of presumably small particles through the epikarst matrix, although addressing this is challenging because of difficulty in accessing the epikarst structure. It is unkown if detritus size distribution differed in the epikarst drip water and cave stream water. Such size partitioning has not been conducted in cave systems although is has been shown to be critically important in organic matter transport in surface streams (Thomas et al. 2001).

The transport of organic matter as dead detritus and living animals appears to be governed at least partially by different factors. In both the epikarst and the cave stream detritus flux and mineral flux were strongly related. In the epikarst the SMA slope was very close to 1 suggesting detritus transport almost perfectly mirrored mineral material transport. The SMA slope in the cave stream was shallower but detritus and mineral flux were strongly related. This suggests detritus flux is quite passive and factors that drive it are closely aligned with factors that drive sediment flux. Of course, this likely only applies to very fine sediments as would likely have been moving through the Dorvan epikarst. In contrast, animal flux was unrelated to transport of mineral material. This likely represents behavioral drift by animals, which has been the subject of much study (Gibert 1986; Rouch 1986). Considering much of the organic matter flux in the epikarst was in the form of living animals, behavior may play a significant role in organic matter distribution in epikarst habitats. 
Gibert (1986) used a pioneering approach of combining drift sampling of animals in karst based on the work of Rouch (1986) with the organic matter budgeting used in surface streams. More than thirty years later her data remain the most comprehensive set of data on organic matter flux in a karst aquifer. While this budgeting process has been extensively used in surface systems with some systems having decades of flux and stocks measures (e.g. Wallace et al. 1995) it has not been commonly applied to cave streams. Such work is labor intensive, but it provides the basis for developing mechanistic models of organic matter dynamics in aquatic systems which are sorely needed to interpret ecological patterns. A growing body of work focusing on the nature of energy limitation and ecological interactions in cave food webs would be well served by basic data regarding how organic matter moves through cave systems. Recent demonstration of linkages among detritus, microbial respiration, $\mathrm{CO}_{2}$ and limestone dissolution (Covington et al. 2013) show such data may also help explain physical processes in karst aquifers. Gibert's work has illuminated how epikarst driven systems function but it also raises new questions. If the flux of organic matter from the epikarst as animals exceeds that of detritus what fuels that animal production? How strongly connected are the fine fracture systems of the epikarst with the cave streams that drain them? How do cave streams with larger openings compare and what dictates energy flux through those systems? Such questions will be well served by the type of approach used by Gibert in the Dorvan karst.

\section{ACKNOWLEDGEMENTS}

This manuscript is dedicated to Janine Gibert, a true pioneer in karst ecosystem science.

\section{REFERENCES}

Benfield, E.F., 1997: Comparison of litterfall input to streams.- Journal of the North American Benthological Society, 16, 104-108.

Birdwell, J.E. \& A.S. Engel, 2010: Characterization of dissolved organic matter in cave and spring waters using UV-Vis absorbance and fluorescence spectroscopy.- Organic Geochemistry, 41, 3, 270-280.

Cooney, T.J. \& K. S. Simon 2009: Influence of dissolved organic matter and invertebrates on the function of microbial films in groundwater.- Microbial Ecology, 58, 599-610.

Covington, M.D., Prelovšek, M. \& F. Gabrovšek, 2013: Influence of $\mathrm{CO}_{2}$ dynamics on the longitudinal variation of incision rates in soluble bedrock channels: Feedback mechanisms.- Geomorphology, in press.

Gibert, J., 1986: Ecologie d'un systeme karstique jurassien. Hydrogéologie, dérive animale, transits de matières, dynamique de la population de Niphargus (Crustacé Amphipode).- Mémoires de Biospéologie, $13,1-379$.
Gibert, J., Vervier, P., Malard, F., Laurent, R. \& J.L. Reygrobellet, 1994: Dynamics of communities and ecology of karst ecosystems: Example of three karsts in Eastern and Southern France.- In: J. Gibert et al. (eds.) Groundwater Ecology. Academic Press, pp. 425-450, San Diego.

Goodman, K.S., 1980: The estimation of individual dry weight and standing crop of harpacticoid copepods.- Hydrobiologia, 72, 253-259.

Golladay, S.W., 1997: Suspended particulate organic matter concentration and export in streams.- Journal of the North American Benthological Society, 16, 1, 122-131.

Graening, G.O., \& A.V. Brown, 2003: Ecosystem dynamics and pollution effects in an Ozark cave stream.Journal of the American Water Resources Association, 39, 497-505.

Huntsman, B.M., Venarsky, M.P. \& J.P. Benstead, 2011: Relating carrion breakdown rates to ambient resource level and community structure in four cave stream ecosystems.- Journal of the North American Benthological Society, 30, 882-892. 
Hüppop, K., 2000: How do cave animals cope with the food scarcity in caves?, In: H. Wilkens, H., Culver, D.C., \& Humphreys, W.F.. (eds.), Subterranean Ecosystems. Elsevier, pp. 159-188, Amsterdam.

Kinsey J., Cooney, T.J. \& K.S. Simon, 2007: A comparison of the leaf shredding ability and influence on microbial films of surface and cave forms of Gammarus minus Say.- Hydrobiologia, 589, 199-205.

O'Doherty, E.C., 1985: Stream-dwelling copepods: their life history and ecological significance.- Limnology and Oceanography, 30, 3, 554-564.

Poulson, T.L. \& K.H. Lavoie, 2001: The trophic basis of subsurface ecosystems.- In: Wilkens, H. et al. (eds.) Ecosystems of the World; Subterranean Ecosystems. Elsevier pp. 231-250, New York

R Development Core Team, 2010: R version 2.11.1 R Project for Statistical Computing, Vienna, Austria. www.r-project.org

Rouch, R., 1986: Sur l'écologie des eaux souterraines dans la karst.- Stygologia, 2, 352-398.

Sarbu, S.M., Kane, T. C. \& B. F. Kinkel, 1996: A chemoautotrophically based cave ecosystem.- Science, 272, 1953-1955.

Schade, J.D. \& S.G. Fisher, 1997: Leaf litter in a Sonoran desert stream ecosystem.- Journal of the North American Benthological Society, 16, 612-626.

Simon, K.S., Gibert, J., Petitot, P. \& R. Laurent, 2001: Spatial and temporal patterns of bacterial density and metabolic activity in a karst aquifer.- Archiv für Hydrobiologie, 151, 67-82.

Simon, K.S., \& E.F. Benfield, 2001: Leaf and wood breakdown in cave streams.- Journal of the North American Benthological Society, 482, 31-39.

Simon, K.S., Benfield, E.F. \& S.A. Macko, 2003: Food web structure and the role of epilithic films in cave streams.- Ecology, 84, 2395-2406.

Simon, K.S., Pipan, T. \& D.C. Culver, 2007: A conceptual model of the flow and distribution of organic carbon in caves.- Journal of Cave and Karst Studies, 69, 2, 279-284.
Simon, K.S., Pipan, T., Ohno, T. \& D.C. Culver, 2010: Spatial and temporal patterns in abundance and composition of dissolved organic matter in two karst aquifers.- Fundamental and Applied Limnology, 177, 2, 81-92.

Souza-Silva M., Ferreira de Olivera Bernardi, L., Parentoni Martins, R. \& R. Lopes Ferreira, 2012: Transport and consumption of organic detritus in a neotropical limestone cave.- Acta Carsologica, 41, 1, 139-150.

Thomas, S.A., Newbold, J.D., Monaghan, M.T., Minshall, G.W., Georgian, T. \& C.E. Cushing, 2001. The influence of particle size on seston deposition in streams.- Limnology and Oceanography, 46, 14151424.

Venarsky, M.P., 2012: The influence of energy availability on population-, community- and ecosystem-level processes in cave stream ecosystems. Doctoral Dissertation. The University of Alabama. $136 \mathrm{pp}$.

Venarsky, M.P., Benstead, J.P. \& A.D. Huryn, 2012: Effects of organic matter and season on leaf litter colonisation and breakdown in cave streams.- Freshwater Biology 57, 4, 773-786.

Wallace, J.B., Whiles, M.R., Eggert, S., Cuffney, T.F., Lugthart, G.J. \& K. Chung, 1995: Long-term dynamics of coarse particulate organic matter in three Appalachian mountain streams.- Journal of the North American Benthological Society, 14, 217-232.

Webster, J.R., Benfield, E.F., Ehrman, T.P., Schaeffer, M.A, Tank, J.L., Hutchens, J.J. \& D.J. D’Angelo, 1999: What happens to allochthonous material that falls into streams? A synthesis of new and published information from Coweeta.- Freshwater Biology, 41, 687-705. 